\title{
MODELLING APPROACHES FOR RECOGNITION OF THE STRATEGIC VALUE OF INFORMATION MANAGEMENT
}

\author{
Yücel YILMAZ
}

Marmara Üniversitesi, İ.I.B.F., Almanca Enformatik Bölümü, Araştırma Görevlisi

\begin{abstract}
Özet: Bilgìye ulaşmantn kolaylaşmast erişilebilen bilgi miktarın artırmtştr. Bilgi miktarnda meydana gelen artıs, işletmelerin "Bilgi Yönetim Konsepti" ne geçmelerini zorunlu kılmaktadir..Bu makalede öncelikle Bilgi Teknolojileri' nin "Global IS Yönetimi" açısından rolüne değinilmiştir. Ikinci bölümde "Veri", "Bilgi" ve "Değerli Bilgi" kavramlart açıklanmiştır. Üçüncü bölümde "Bilgi Yönetimi" kavramı işlenmiş, son bölümde ise, Bilgi Yönetimi' nin ifade ettiği stratejik değerin belirlenmesinde kullanilan yöntemler ele altnmiştır.
\end{abstract}

\section{THE ROLE OF INFORMATION TECHNOLOGIES (IT) IN GLOBAL BUSINESS MANAGEMENT}

Searches for global efficiency imply that the organization must be able, within each relevant function, to co - ordinate and consolidate its activity to achieve available economies of scale. A key requirement would seem to be the collection of comparative performance information from locations around the world to support decisions on how effectively to allocate resources and source requirements. This need may be facilitated by building a global data network, collecting and providing access to information which conforms to some globally applied data standards [1].

Organizations often wish to go further, to implement standard application systems worldwide, in order to ensure the integrity of information, facilitate the transfer of activities and people, and perhaps achieve scale economies in systems development and processing. Conceptually, however, the base requirement is for the definition and communication of standard data [1].

Expert systems and databases which codify or provide accepted knowledge are likely to be derivatives of a public good and of useful, but not often firm - specific, value. Decision support tools which craft and make available workable knowledge are likely to be more private and thus competitively valuable. Transaction processing systems which capture potential knowledge and arrange it in databases are likely to be firm - specific and continuously providing a source of strategic value [2].

\section{WHAT IS INFORMATION?}

Since the use of information and communication technologies is called data processing, information processing and often as knowledge processing, this suggests, data, information and knowledge are the same. That is not surely like that, aithough contents of the term information are still controversially discussed today. In the following the connections between characters, data and information are represented.

On the lowest level a large supply of different characters is as base of all terms further settled above. If the characters are assigned to an alphabet, one can speak of data. The enrichment with additional context provides the meaning for the data, so that information develops.

Schwarze defines information as indicated and taken up components of knowledge. They are derived from knowledge and should extend and / or update the recipient's knowledge [3].

Information is each knowledge, which can be used purpose - referred and which indicates decision and action relevance. In order to be able to form information, knowledge must be available, which represents a stock of knowledge of action and experience relations. This is first as subjective knowledge a mixture from intuition, experience and judgement, according to objective, which can extend and it can be transferred an objective knowledge. Knowledge possesses thus a semantic level; beyond this information possesses a pragmatic level [4]. 


\section{Example:}

Character set: "1", "7", "0" and. ","

Data: 1.70

Information: Foreign exchange rate: $\$ 1=D M 1.70$

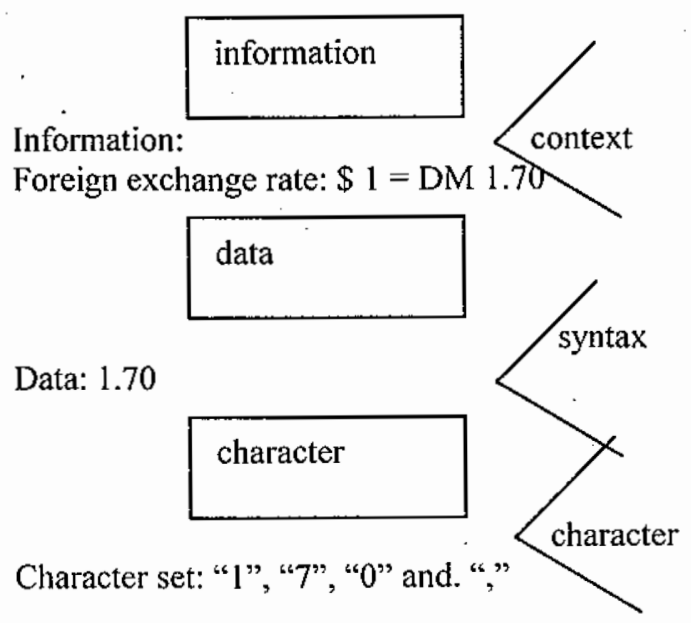

Figure.1: Relationships between levels of the term hierarchy [5]

\section{TARGETS and FUNCTIONS OF THE INFORMATION MANAGEMENT}

Information management is to be understood in of following in very global sense as the quantity of all activities, which have the data processing of a business and its organization as a goal. Data processing can be automated or not automated, both types are the subjects of the information management. Information management is not limited on executive functions, but it includes all activities, which we traditionally relate to data processing with a department in business [6].

Targets of the information management are real objectives and formal objectives. The real objectives describe the purpose of the information management; the formal targets describe with which quality the real objectives are to be achieved. General real objective of the information management is to determine the performance potential of the information function for the achievement of the strategic targets of the organization and to make this usable through supplying a suitable information infrastructure.

The organization is regarded as a whole. General formal target of the information management is the rantability. The reaching of the real objective of the information management is thus to take place in the long run in such a way that with given costs of the information infrastructure the implemented use is maximum; or that with a given use the costs of the information infrastructure are insignificant [7].

The functions of the information management can be divided in three groups.

These are:

- strategic functions,

- tactical functions and

- operational functions.

Strategic functions are related with decisions, which determine the business on long time. These are fundamental decisions, which determine the direction. Strategic functions are essentially prognosis -, planning and executive functions. Tactical functions are related with decisions of medium - term consequence. In the information management also administrative functions and development functions occur within this area apart from planning functions. Operational functions require fast decisions. Naturally they also require planning, but this planning is for short term created and takes place frequently only in our heads [5].

\section{THE STRATEGIC INFORMATION MANAGEMENT}

In a manner similar to corporate strategic management (i.e. the high - level management of a portfolio of business), strategic IT management is concerned with the group - wide management of a portfolio of IT resources and capabilities. This involves many activities in common with strategic management, such as; organizational mission and goal formulation, formulation of strategies to achieve goals, strategy implementation and strategic control [8].

Strategic information systems (SIS) is one in a string of miracle cures offered up by the information systems community to an increasingly wary audience of senior managers and directors. SIS is one of the alphabetic elixirs of information technology along side Data Bank -Management Systems (DBMS), Decision Support Systems (DSS), Executive Information Systems (EIS) and Artificial Intelligence (AI). Unlike the others, which focused primarily on internal efficiency, the SIS cure is usually targeted specifically at a firm's products, customers, distribution channeis or suppliers [9].

In order to be able to recognize the strategic value of the application of information systems, different models were developed. 


\section{A. Benjamin / Rockart - Model}

Benjamin, Rockart suggest a matrix with four fields, which differentiates on the one hand between the meaning of the information technology for market position and enterprise - internal operational sequence, on the other hand between the IS application for available projects or processes and new business fields. Each existing or planned information system of an enterprise can be arranged in a quadrant of the matrix.

To the first group belong the information systems, which influence the market position of an enterprise by modification of the products. The second group contains information systems which are based on technical developments (e.g. CAD / CAM systems) and which involve fundamental modifications of internal operational sequence. Information systems, which support available market functions of the enterprise (e.g. information systems for the support of the field service), are assigned to the third group. If the support refers to available internal function fulfillment processes, then these information systems belong to the fourth group.

$$
\begin{array}{ll}
\text { Market position } & \begin{array}{l}
\text { Internal } \\
\text { operational } \\
\text { sequence }
\end{array}
\end{array}
$$

\begin{tabular}{l|l|c|}
\cline { 2 - 3 } New business-fields & 1 & 2 \\
\cline { 2 - 3 } $\begin{array}{l}\text { Available products } \\
\text { and processes }\end{array}$ & 3 & 4 \\
\hline
\end{tabular}

Figure.2: Strategic Opportunities Framework [10]

\section{B. Mcfarlan / Mckenney - Model}

A discussion of the targets, the functions and the methodology of the information management presuppose first that one provides over the potential amount of performance (performance potential) of the information function for the reaching of the strategic targets of an organization clarity.

If the performance - potential is little at the moment and if it is prognosticated also for the future as little, a little value of the information management results from it. If the performance potential is large at the moment and if it is prognosticated also for the future as large, a substantial value of the information management results from it. This thought is specified as follows concerning the information management:
One differentiates between the attributes present and future (prognosticated) performance development potential of the information function as well as between little and large to these attributes. Then the organization types shown in figure three result.

McFarlan makes a classification after strategic meaning of existing and future information systems: [11]

\section{Support}

Independently of the range of the data processing budget, enterprises, whose daily transactions depend not necessarily on perfect functioning of the data processing, belong to this group. On the other hand the even systems in the development do not indicate a strategic content. In enterprises of this type it is thus inappropriate to bring the management or the Top management into information system planning. Accordingly, the data processing department is anchored in such enterprises on a relatively low leadership level.

\section{Factory}

The daily transaction of enterprises, which belong to this group, depends in crucial measure on the services of its data processing. Here, data processing failures can lead to the collapse of the business activities. The development concern maintenance of existing applications or such systems, which are taken justified for itself, however no contribution for the competitive ability of the enterprise carry out. Data processing planning is here essentially at short term oriented at operational targets. In the focal point of planning, the service degree and costs of the data processing are located,

\section{Turnaround}

With enterprises of this group the daily activities do not hang in crucial measure of functioning the data processing yet. Nevertheless are the works, which are in the development, for the enterprise of critical interest. According to this increasing meaning, both top management and data processing users are to be integrated strengthened into IS planning in enterprises of this type.

\section{Strategic}

Here enterprises are to be arranged, in which the daily transaction does not only depend crucially on functioning the data processing, but also the current system developments for the competitive ability of the enterprise are substantial. In such enterprises a critical function comes to information system planning, so that the data processing department is high - ranking arranged 
in the enterprise hierarchy. The data processing executive can be even a member of the management.

\begin{tabular}{|c|c|c|}
\hline \multirow{2}{*}{$\begin{array}{l}\text { Strategic impact } \\
\text { of existing } \\
\text { operating } \\
\text { systems }\end{array}$} & Factory & Strategic \\
\hline & Support & Turnaround \\
\hline
\end{tabular}

Figure.3: Position of Information Systems in various types of companies [12]

\section{THE COMPARISON OF THE TWO APPROACHES}

The problems of the approach of Benjamin / Rockart consists of it that in the reason each information system can be arranged in one of the four fields, thus strategic values would have [11].

The Approach is however suitable to point the objective of existing or planned applications of the information technology. To that extent it supplies reference points regarding the meaning of existing or in planning of applications present.

The model of McFarlan / McKenney enables an expression about it, at which stage of the use of information systems an enterprise is. It is important now to recognize that individual branches cannot be assigned overall or others. Even related to the individual enterprise it is possible that different divisions are in different classes. Whether a special information system has strategic significiance, is not to be decided with this model. For this the information system must be referred to the specific enterprise strategy.

\section{CONCLUSION}

During the optimal use of the information as a strategic source the user-fair representation of these information plays an .important role. The management information system must offer the use that it enables a focused discussion about important trends to the general business development through the concentrated representation of relevant information. As an example, it can serve through its application in a special discussion platform for the support of team sessions. In a use with monitor, this can be applied in the same way as assistance for virtual teams.

The realization of the strategic information management concept and the optimal use of the information require that the following barriers [13] in an enterprise must be overcome:

\section{Usage Barriers}

Information management must create contexts, in which the processed information is also actually used. The personal work environment must support the application of the new information and promote the readiness for the use of information on individual and collective platform

\section{Myopia}

The more an individual gets used to its daily tasks, the harder it will usually be to recognize the meaning of the latest information as well as exchanging this information about the new possibilities for the function fulfillment with colleagues.

\section{Cultural Barriers}

Apart from the general inertia regarding the application of previously trusted information, thereby secret rules exist often, which blocks the use of the external information. By the request and use of external information the requesting person goes into a position of vulnerability. He confesses a lack of knowledge through which the other colleagues may underestimate him. The manner, how and with whom he inquires the knowledge prevents additional risks. 


\section{REFERENCES}

[1] EARL, M. J.; FEENY, D. F., Information Systems in Global Business, Oxford University Press, New York, 1996.

[2] EARL, M. J., Knowledge Strategies, Oxford University Press, New York, 1996.

[3] SCHWARZE, J., Informationsmanagement, Verlag Neue Wirtschaftsbriefe, Berlin, 1998.

[4] GABRIEL, R.; GLUCHOWSKI, P.; CHAMONI, P., Management Support Systeme, Springer Verlag, Berlin, 1997.

[5] KRCMAR, H., Informationsmanagement, Springer Verlag, Berlin, 1997.

[6] RAUH, O. Informationsmanagement im Industriebetrieb: Lehrbuch der Wirtschaftsinformatik auf der Grundlage der Integrierten Datenverarbeitung, Neue Wirtschaftsbriefe, Herne, 1990.

[7] HEINRICH, J. L., Informationsmanagement: Planung, Überwachung und Steuerung der InformationsInfrastruktur, Oldenbourg Verlag, Wien / München, 1990.

[8] HODGKInson, S. L., The Role of Corporate IT Function, Oxford University Press, New York, 1996.

[9] IVES, B.; VITALE, M., Strategic Information Systems, Oxford University Press, New York, 1996.

[10] BENJAMIN, R. I.; ROCKART, J. F.; MORTON, M. S.; WYMAN, J., Information Technology: A Strategic Opporturity. -In: Sloan Management Review, Spring, 1984, ss. 3-10.

[11] MARTINY, L.; KLOTZ, M., Strategisches Informations management, Oldenbourg Verlag, München Wien 1989.

[12] McFARLAN, F. W.; McKENNEY, J.; PYBURN, P.: The Information Archipelago - plotting a course. - In: Harward Business Review, January - February 1983, (1/1983), ss. $145-146$.

[13] PROST, G.; RAUB, S; ROMHARDT, K., Wissensmanagen, 2. Auflage, Wiesbaden, 1998. 